\title{
Understanding the Ethical Theories in Medical Practice
}

\author{
Ahmed Bait Amer \\ Sultan Qaboose University Hospital, Muscat, Oman \\ Email: ahmedsaid-777@hotmail.com
}

How to cite this paper: Amer, A.B. (2019) Understanding the Ethical Theories in Medical Practice. Open Journal of Nursing, 9, 188-193.

https://doi.org/10.4236/ojn.2019.92018

Received: January 14, 2019

Accepted: February 22, 2019

Published: February 25, 2019

Copyright (C 2019 by author(s) and Scientific Research Publishing Inc. This work is licensed under the Creative Commons Attribution International License (CC BY 4.0).

http://creativecommons.org/licenses/by/4.0/

\begin{abstract}
It is important to understand the basic of the ethical theories and how to utilize them to deal with the ethical dilemma in the medical practice. This article presents a brief review of three of famous philosophical theories of ethics, which may enrich our understanding and guide our behaviour in medical practice. Conclusion: There is no fully adequate moral theory which can singly explain all ethical or moral dilemmas and none of them also can singly explain all ethical or moral dilemmas.
\end{abstract}

\section{Keywords}

Ethical Theory, Utilitarianism, Teleology, Deontology, Principlism

\section{Introduction}

Clinicians have specific duties of care to their patients and to society. It is generally held that clinicians should always act in the best interest of their patients; but sometimes there is a conflict between obligations to a patient and those perceived to be owed to the community or to other patients. It may not always be the case that what the clinician believes is in the best interest of the patient or is what the patient wishes or will consent to [1]. The ethical theories provides an ordered set of moral standards to be used in assessing what is morally right and what is morally wrong regarding human action in general [2].

\section{The Ethical Theory}

Is a theory of moral obligation their proponent puts it forth as a framework within which a person can correctly determine, on any given occasion, what he or she (morally) ought to do [2]. We will discuss three common ethical theories and how it handle the case of truth telling in medical practice as an example. 
Teleology and Utilitarianism, deontology, and principlism, these theories can be applied in several procedures of ethical analysis, such as in analysis of cases (casuistry) and in different settings, moral or ethical theory may consider the application of rules or the consequences of actions [3]. Their advantages and disadvantage were shown in Table 1.

\subsection{Teleology and Utilitarianism}

Teleology comes from the Greek for goal (telos) and theory (logos); teleological theories stress the consequences of actions as the first step in analyzing moral activity; consequentialism is another name given to this class of theories [4]. It primarily refers to moral views or theories which base their evaluations of acts solely on consequences [5]. Consequentialism sees the rightness or the wrongness of an action in terms of the consequences brought by that action [6] or according to the balance of their good and bad consequences [7]. The most common, but not the only, form of consequentialism is utilitarianism or social consequentialism holds that one should act as to do the greatest good for the greatest number [5]. The major philosophers who developed the utilitarian approach were Jermy Bentham (1748-1832) and John Stuart Mill (1806-1873). Utilitarianism is the moral/ethical theory that states that right actions ought to produce the greatest happiness for the greatest number of people [6]. Bentham and Mill are hedonistic utilitarian's because they conceive utility entirely in terms of happiness or pleasure, two broad terms that they treat as synonymous [6], J. S. Mill defined good as the presence of pleasure and the absence of pain [5]. Utilitarianism concentrate on value of well being, which may be analyzed in terms of pleasure, happiness, welfare, preference satisfaction or the like, they accept only one basic principle of ethics: the principle of utility. This principle asserts that we ought always to produce the maximal balance of positive value over disvalue (or the least possible disvalue, if only undesirable results can be achieved [6]. This principle is the main aspect of the consequent list theory which has been put forward by Bentham and Mill as a universal moral truth, and it is the ultimate standard of right and wrong for all the utilitarian's [5], actions are right in proportion as they tend to promote happiness, wrong as they tend to produce the reverse of happiness so it is the demand to produce the greatest balance of good over evil [2], from the utilitarian's perspective the principle of utility is the sole

Table 1. Types of the ethical the ethical theory their advantages and disadvantages.

\begin{tabular}{|c|c|c|}
\hline Types of the theory & Advantages & Disadvantages \\
\hline $\begin{array}{c}\text { Consequence-based } \\
\text { (Utiltarian) }\end{array}$ & $\begin{array}{l}\text { Stresses promotion of } \\
\text { happiness and utility }\end{array}$ & $\begin{array}{l}\text { Ignores concerns of justice } \\
\text { for the minority population }\end{array}$ \\
\hline $\begin{array}{l}\text { Duty-based } \\
\text { (Deontology) }\end{array}$ & $\begin{array}{l}\text { Stresses the role of duty } \\
\text { and respect for persons }\end{array}$ & $\begin{array}{l}\text { Underestimates the importance } \\
\text { of happiness and social utility }\end{array}$ \\
\hline Principlism & $\begin{array}{l}\text { Provide a set of moral } \\
\text { commitments, common language } \\
\text { and a common set of moral issue }\end{array}$ & $\begin{array}{l}\text { Not designed to provide } \\
\text { a method for choosing }\end{array}$ \\
\hline
\end{tabular}


and absolute principle of ethics [3]. In contemporary discussions, distinction is made between two kinds of utilitarianism act utilitarianism and rule-utilitarianism. The Act utilitarianism: asks what good and bad consequences will probably result from this action in this circumstances) whereas the rule-utilitarian consider the consequences of adopting certain rules the act utilitarian's disregards the level of rules and justifies actions by direct appeal to the principle of utility [6]. In the spirit of rule utilitarianism, a moral code is first established by reference to the principles Utility. That is a set of valid moral rules is established by determining which rules as opposed to conceivable alternatives, if generally followed would produce the greatest balance of good over evil. In rule-utilitarianism, individual actions are morally right if they are in accord with those rules [2] in the truth telling case, the utilitarian effort to do the right thing may place truth telling secondary to not distressing the patient and therefore an outright lie could be morally justified [5] (Table 1).

\section{Criticism of Utilitarianism}

This theory has been criticized for the fact that one cannot predict the outcome of actions in advance, thus it is impossible to set the standers of one's moral action on the basis of the act itself [3]. Problems arise for utilitarian's who are concerned about the maximization of individual preferences when some of these individuals have considered what judgments tell us are morally unacceptable preferences also an additional problem concerned with immoral actions. Suppose the only way to achieve the maximal utilitarian outcome is to perform an immoral act such as killing one person to distribute his organs to several others who will die without them. Utilitarianism seems to say not only that such killing is permissible, but that it is morally obligatory [7].

\subsection{Duty Ethics (Deontology)}

It denies much that utilitarian theories affirm. Often called deontological or Nonconsequentialist [7]. The term "deontology" is a modern combination of classical Greek terms and means the study or science (logos) of duty, or more precisely of what one ought to do (Deon) [5]. It involves applying the same rule for every one in all circumstances; the main proponent is Immanuel Kant for that it was called Kantianism (1724-1804) [8]. In his theory morality provides a rational framework of universal principles and rules that constrain and guide everyone. Kant's supreme, supreme principle of morality, the principle from which all of our various duties derive, is called by Kant the "Categorical Imperative" and is expressed in several ways in his writings. His first formulation: I ought never to act except in such a way that I can also will that my maxim become a universal law. Kant says that this principle justifies all particular imperatives of obligation (all "ought" statements that morally obligate "This imperative tells us what must be done irrespective of our desires and the maxim must be capable of being conceived and willed without contradiction" [7]. The second formulation is "Act in such way that you always treat humanity whether in your 
own person or in the person of any other, never simply as a means, but always at the same time as an end". The first formulation has often been compared with the golden rule (do unto others as you would have them do unto you) [2]. Unlike utilitarian's, deontologists hold that lying is wrong even if a lie would accomplish great good for individuals and society [7]. Kant argued for truth and the strict rejection of all lying. In Kant's categorical imperative doctrine, truth telling is a duty (imperative) which binds unconditionally (categorical). A lie is always evil for Kant because it harms human discourse and the dignity of every human person. Truth telling is always a duty, whether the other has the right to know or whether innocent persons will be severely harmed [9] (Table 1).

\section{Criticism to Deontology}

Deontology cannot within itself provide for resolution of conflicts among two or more moral persons who profoundly disagree.

\subsection{Principlism}

Is a widely applied ethical approach based on four fundamental moral principles sometimes referred to as "the big four" developed in the 1970s by the Americans Tom Beauchamp and James Childress [10]? Identify four primary principles as the followings: 1. Respect for autonomy, 2. Non-Malfeasance, 3. Beneficence (including utility) and 4 . justice and several derivative rules: veracity, fidelity, privacy and confidentiality along with various other rules such as informed consent. Danner Clouser and Bernnard Gert (1990) coined the label principlism. Others have [5] called this frame work the four principles approach (the principlism approach argue that the four principles that are included in principlism express "the general values underlying rules in the common morality"), where the common morality is "the set of norms that all morally serious persons share" [11] and to be applied to solve the contemporary ethical dilemmas [9]. Beauchamp and childress had said that principlism has proved a popular framework for thinking about medical ethics, and often forms part of the education for those coming into medicine. It is not intended to be a general moral theory, but rather aims to provide a framework to help those working in medicine both to identify moral problems and to make decisions about what to do. Similarly, Raanan Gillon has claimed that the four principles can explain and justify all the substantive and universalisable moral claims in medical ethics [11]. Although this approach is sometimes criticized for its lack of foundational theory and its Western-dominated methodology, principlism is widely used as a starting point for practical ethical decision-making in the clinical, technological and epidemiological professions [10].

\section{Criticism to Principlism}

They are not designed to provide a method for choosing, but rather provide a set of moral commitments, common language and a common set of moral issue (Table 1). 
- Failing to act as action guides [12]. The truth telling case the four principle are all equally important for guiding the discussion and resolution of the clinical dilemma of what to tell the patient

\subsection{Correlations among the Above Three Ethical Theories}

As we notice from the above, each one of the ethical theories had advantages and also disadvantages and the correlation among them showed that ethics is not a prescription or set of rules to be followed blindly. There is rarely a single "right" answer to the ethical dilemmas in practice, but ethics involves a systematic approach to moral dilemmas. Patients and society should be confident that difficult choices are not dealt with in an arbitrary fashion, or simply dependent on the particular moral stand taken by clinicians. Choices should be made or presented fairly and usually in the best interests of the patient. Ethics is just us much about HOW dilemmas are resolved than with WHAT the right choices or actions should be. Central to modern clinical ethics is the dignity and respect for the patient as individuals capable of understanding and where possible taking decisions about their treatment [13].

\section{Conclusion}

As we notice from the above mentioned theories every one had it is own advantages, and disadvantages. I agree with Kasule [14] who conclude; there is no fully adequate moral theory which can singly explain all ethical or moral dilemmas and none of them also can singly explain all ethical or moral dilemmas. None of them taken singly has the attributes of a good ethical theory: clear, coherent, complete, comprehensive, simple, practicable, and able to explain and justify. In practice more than one theory may have to be combined to solve a specific ethical issue.

\section{Conflicts of Interest}

The author declares no conflicts of interest regarding the publication of this paper.

\section{References}

[1] https://www.researchgate.net/publication/282670338

[2] Mappes, T.A. and Zembaty, J. (1986) Biomedical Ethics and Ethical Theory. 2nd Edition, Mcgraw-Hill Book Company, New York.

[3] Slowther, A., Johnston, C., Goodall, J. and Hope, T. (2004) A Practical Guide for Clinical Ethics Support. Section C: Ethical Frameworks, University of Oxford, Oxford.

[4] Thomasma, D.C. (2003) Military Medical Ethics. Borden Institute, USA.

[5] Becker, L. and Becker, C.B. (2001) Encyclopedia of Ethics. Routledge, London and New York.

[6] Garrett, T.A., Baillie, H.W. and Garrett, R.M. (2000) Health Care Ethics Principles and Problems. 4th Edition, Prentice Hall, Upper Saddle River. 
[7] Beauchamp, T.L. and Childress, J.F. (2009) Principles of Biomedical Ethics. 6th Edition, Oxford University Press, USA.

[8] Christine, H. (1995) Professional Ethics and Organizational Change in Education and Health. Edward Arnold, Great Britain.

[9] Drane, J.F. (2002) Honesty in Medicine: Should Doctors Tell the Truth? American Journal of Bioethics, 2, 14-17.

[10] Lucy, C. (2005) A Primer to Ethical Analysis. Office of Public Policy and Ethics: Institute for Molecular Bioscience, University of Queensland, Brisbane.

[11] Walker, T. (2009) What Principlism Misses. Journal of Medical Ethics, 35, 229-231. https://doi.org/10.1136/jme.2008.027227

[12] Gillon, R. (1994) Medical Ethics: FOUR Principles plus Attention to Scope. BMJ, 309, 184-188.

[13] Noble, R. Introduction to Medical Ethics. https://www.researchgate.net/publication/282670338

[14] Kasule, O.H. (2005) Medical Ethics from Maqasid Al Shari'at. Journal of ISHIM, 4, 1-12. https://www.ishim.net/ishimj/jishim4_7_8/Vol4No7/kasule.doc 